\title{
Study of the Content of Somatic Cells in Cow's Milk in Armenia
}

\author{
E.B. Balayan, A.E. Araksyants \\ Armenian National Agrarian University \\ eduard.balayan.2000@bk.ru, andaraks@gmail.com
}

\section{A RT I CLE I N F O}

Keywords:

somatic cells, mastitis,

high quality milk, healthy animals, cow udder

\begin{abstract}
A B S T R A C T
The aim of the research is to understand the quality of milk and the state of animal health in Armenia, using the Somatic Cell Counts (SCC) as an indicator. As a result, we have received a clear map of milk quality in five regions of the Republic of Armenia, the data of which are extremely alarming. According to the SCC, $12 \%$ of 135 animals have clinical mastitis, $23 \%$ have developed mastitis and the remaining $65 \%$ do not have mastitis. To improve the quality of milk and the state of animal health, we suggested that processing companies apply a financial scheme of incentives and penalties to suppliers.
\end{abstract}

\section{Introduction}

One of the main preconditions for getting high quality milk is a healthy cow's udder. Milk from an animal with mastitis is not only a source of staphylococcal and streptococcal infections, but also a cause of the spread of pathogenic bacteria.

The high number of leukocytes due to the penetration of microorganisms into the udder cavity promotes the growth of somatic cells (SCC) in milk, which is the first symptom of mastitis. Separately, high numbers of SCC do not affect the quality of milk, but they "warn" of impending danger. Usually the average amount in raw milk can be in the range of $50 \times 10^{3}-100 \times 10^{3} \mathrm{SCC} / \mathrm{ml}$. In the case of an inflammatory lesion, the number of somatic cells increases sharply (Araksyants, 2016).

Milk quality and animal health indicators vary from country to country. According to the technical regulations of the Eurasian Economic Union (CU TC 021/2011), the permissible amount of SCC in raw milk must be $750 \times 10^{3} \mathrm{SCC} / \mathrm{ml}$, including baby food, cheese, raw milk used for the production of sterilized milk - not more than $500 \times 10^{3} \mathrm{SCC} / \mathrm{ml}$.

One $\mathrm{ml}$ of healthy cow's milk contains less than $100 \times 10^{3} \mathrm{SCC}$. When mastitis is suspected, SCC reaches $500 \times 10^{3} \mathrm{SCC} / \mathrm{ml}$, more than $500 \times 10^{3} \mathrm{SCC}$ indicates clinical mastitis (https://fsvps.gov.ru/).

Statistics on the control of mastitis and milk quality in EU dairy farms is as follows:

- A mastitis incidence rate of no more than 30 cases per 100 cows per year

- A mastitis persistence rate of no more than $20 \%$ of the herd affected per year 
- A mastitis re-occurrence rate - less than $10 \%$ of the total number of cases

- A herd-average Somatic Cell Count below $150 \times 10^{3} \mathrm{SCC} / \mathrm{ml}$

- An average BactoScan result - below $5 \times 10^{3}$.

The practical tests have proven that for every $100 \times 10^{3}$ cells $/ \mathrm{ml}$ increase in the herd bulk SCC, there is an $8-10 \%$ increase in the proportion of cows infected in the herd. Persistently high individual cow SCC results can indicate chronic mastitis problems (https://ahdb.org.uk).

\section{Materials and methods}

The study was carried out in five regions of Armenia: Kurtan and Katnaghbyur villages of Lori and Azatan village of Shirak regions from the North part of Armenia, Khachaghbyur and Lusakunk villages of Gegharkunik region from the Eastern part, Geghashen village of Kotayk region from Middle part, Aragatsavan and Shenik villages of Aragatsotn region from the Western part. A total of 135 farms were selected and the sample of cow's bulk milk was taken within 2 hours at milking temperature from 6 to $8{ }^{\circ} \mathrm{C}$ to evaluate the SCC. To get accurate results, the analysis of the milk was performed in triplicate. The results of milk analyses for the content of SCC were statistically processed.

At present, SCC in milk is not measured on farms in Armenia. In case of mastitis, speed and accuracy are critical. We know that the best way to accurately measure the number of somatic cells is to count the number of somatic cells under a microscope, which can be time consuming and, in most cases, impossible to do on the farm. The DeLaval DCC somatic cell counter calculates the number of cells automatically. A digital camera takes a picture of the nuclei of somatic cells and counts them one by one. You get an accurate measurement within one minute, which enables to act as quickly as possible (https://www.journalofdairyscience.org/).

The DeLaval (DCC) Somatic Cell Meter (Made in Sweden) allows accurate testing in both laboratory and industrial settings. The disposable disc serves as a container for fresh milk during analysis. It contains a small amount of reagent mixed with milk and stains the nuclei of somatic cells. The device has a compact fluorescent microscope: camera. During the examination of each portion of milk, two photos were taken, the average result is displayed on the screen counter. The use of this device excludes the influence of the human factor on the result of the analysis, at the same time allows to study milk samples directly in the farm, as the meter is portable and is powered by a battery (www.delaval.com).

The DCC allows producers to accurately determine the SCC in milk samples obtained from each cow, in milk collected in a refrigerated container, and to closely monitor the health of cows.

\section{Results and discussions}

If SCC in $1 \mathrm{ml}$ of milk does not exceed $1000 \times 10^{3}$ $\mathrm{SCC} / \mathrm{ml}$, then the share of milk obtained from an animal with mastitis in the total volume of milk procured is less than $6 \%$, that is, the dairy product is safe. However, if the SCC in the stored milk reaches $1000 \times 10^{3} \mathrm{SCC} / \mathrm{ml}$, the volume of milk from an animal with mastitis is up to $30 \%$ and more. Such milk is dangerous because it becomes a real source of pathogenic bacteria. It is quite natural to have a certain amount of somatic cells in milk. There is a clear link between cow production and the SCC in milk (Table 1). Productivity decreases at fairly high levels of somatic cells. As a result of doubling them, $181 \mathrm{~L}$ of milk is lost during 305 days of lactation of the cow (https:// www.ncbi.nlm.nih.gov/).

Table 1. The state of the cow's udder by the number of somatic cells*

\begin{tabular}{|c|c|c|}
\hline $\begin{array}{c}\text { Average Number } \\
\text { of Somatic Cells, } \\
\text { SCC } / \mathrm{ml}\end{array}$ & Udder Condition & $\begin{array}{c}\text { Milk Loss, } \\
\quad \%\end{array}$ \\
\hline Less than $100 \times 10^{3}$ & Very good & 0 \\
\hline $100 \times 103-300 \times 10^{3}$ & Good & 2 \\
\hline $300 \times 103-400 \times 10^{3}$ & $\begin{array}{c}\text { Sufficient } \\
\text { (about } 20 \% \text { of udders } \\
\text { are diseased) }\end{array}$ & 4 \\
\hline $400 \times 103-500 \times 10^{3}$ & $\begin{array}{c}\text { Dangerous } \\
\text { (about } 30 \% \text { of udders } \\
\text { are diseased) }\end{array}$ & 5 \\
\hline $500 \times 103-700 \times 10^{3}$ & $\begin{array}{c}\text { Problematic } \\
\text { (about } 40 \% \text { of udders } \\
\text { are diseased) }\end{array}$ & Above 5 \\
\hline Above $700 \times 10^{3}$ & $\begin{array}{c}\text { Massive lesion } \\
\text { (about } 50 \% \text { of udders } \\
\text { are diseased) }\end{array}$ & Above 12 \\
\hline
\end{tabular}

*Araksyants, 2016. 


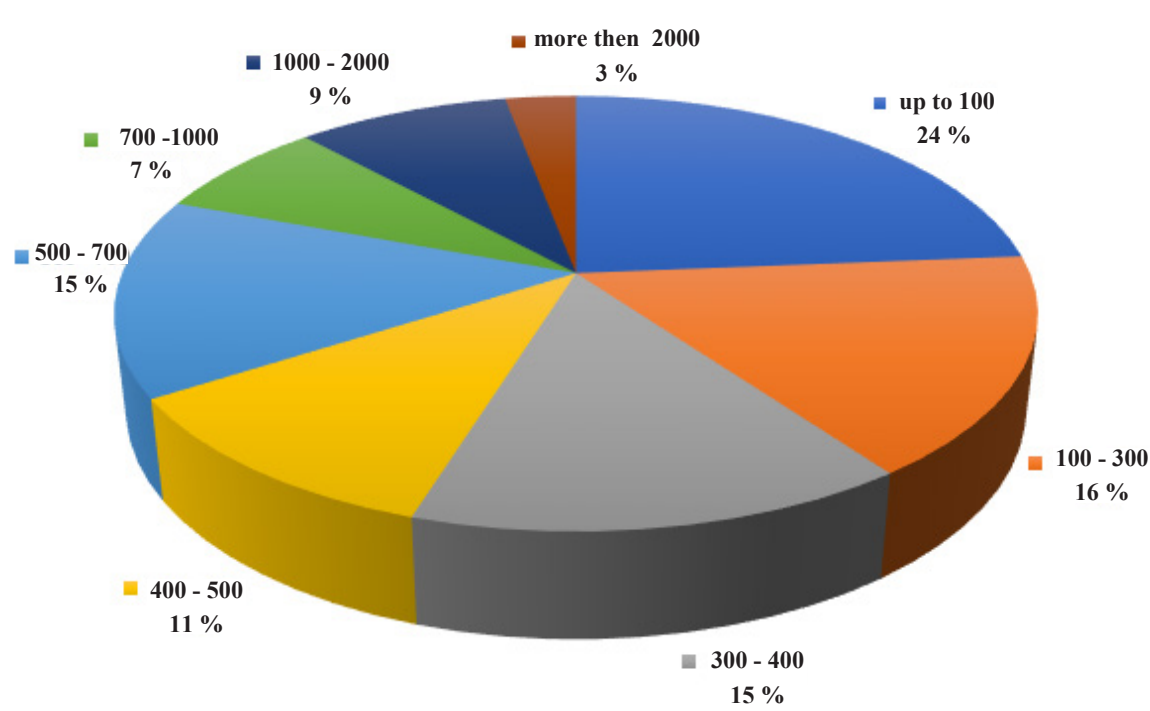

Figure 1. The content $\left(\times 10^{3}\right)$ of Somatic Cells in the milk of Kotayk, Aragatsotn, Lori, Shirak and Gegharkunik regions (composed by the athors).

The high SCC may be due to the breed or inheritance of the animal. Lactation also affects this indicator. Usually during the first and last weeks of lactation, the SCC increases, so the risk of udder inflammation increases. The external environment is also essential. The SCC is higher in summer than in winter, which is due to high humidity, temperature, grazing behavior of cows, exposure to fodder, and other factors. Violation of sanitary and hygienic rules, incorrect way of underfeeding, technical condition of the milking machine, general pollution of the barn, other negative factors contribute to the multiplication of bacteria. As a result, the risk of infectious diseases and the SCC increases (http://milkfacts.info/).

To identify milk produced from animals with mastitis against the overall amount of raw material production, both direct and indirect methods of somatic cell identification are used. Milk quality requirements are constantly being tightened. As an effective means, processing companies apply various financial schemes to suppliers. Therefore, the milk producer should establish daily quality control of the product. Our results are shown in Figure 1.

The SCC is a collective indicator of the sanitary quality of raw milk, according to which the price of its delivery and reception is determined. Thus, the high type in the tested milk was $40 \%$ (no more than $100 \times 10^{3} \mathrm{SCC} / \mathrm{ml}$ ). The European standard is very strict compared to our requirements. The content of somatic cells in raw milk should be up to $75 \times 10^{3} \mathrm{SCC} / \mathrm{ml}$ (https://ec.europa.eu/). Therefore about $24 \%$ of the tested milk meets the above standard. The amount of the first and second type of milk was $48 \%$ (Figure 2). $12 \%$ was incompatible with standard milk (CU TC 033/2013).

Processing companies should apply incentive and penalty schemes for milk delivered to suppliers. As a result of discussions with farmers and milk processing organizations of the given regions, we proposed to increase the price of milk intake by 5 AMD (Armenian currency) per liter if it corresponds to the high type and to reduce the cost of milk intake in case of the second type milk. The proposed classification of milk by type (SCC) is given in Table 2 .

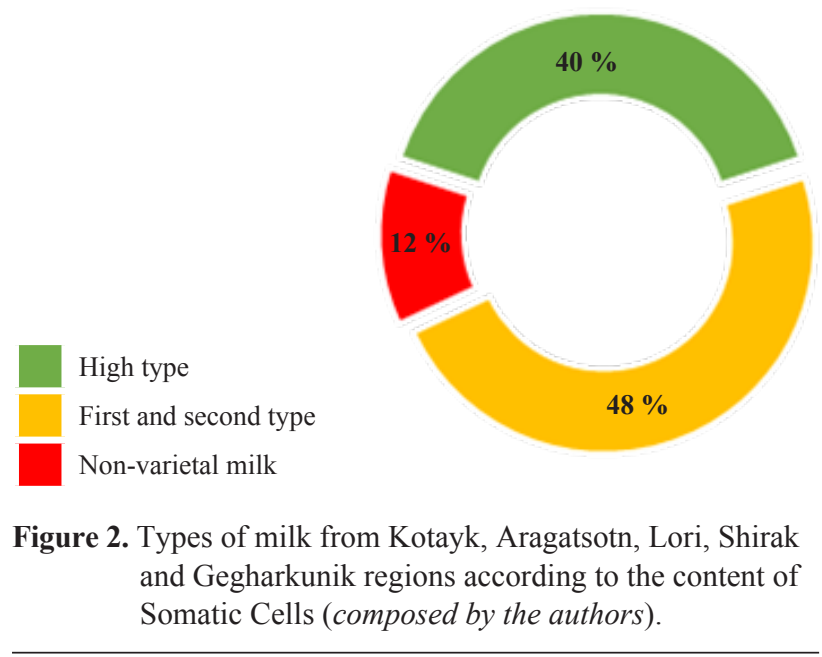


Table 2. Classification of milk by types per the Somatic Cell Count*

\begin{tabular}{|c|c|c|c|}
\hline \multirow{2}{*}{ Indicator } & \multicolumn{3}{|c|}{ Milk Type } \\
\hline & High & $1 s t$ & 2nd \\
\hline $\begin{array}{l}\text { The content of somatic cells } \\
10^{3} \text { in } \mathrm{cm}^{3} \text {, no more }\end{array}$ & 300 & 500 & 1000 \\
\hline $\begin{array}{l}\text { Bonus payment or } \\
\text { discount deduction, AMD } \\
\text { (Armenian currency) }\end{array}$ & +5 & 0 & -5 \\
\hline
\end{tabular}

\section{Conclusion}

The results of the experiments showed a very worrying picture. The high type of milk tested for somatic cells was $40 \%$. The amount of the first and second type of milk was $48 \%$. Non-varietal milk was $12 \%$. Farms involved in the use of somatic cell counters have taken concrete steps to treat and take preventive measures for animals with mastitis.

The use of a somatic cell metering device allows milk processors to supply higher quality milk, to ensure an increase in the yield of the finished product, and to improve the quality. The device for determining the number of somatic cells is indispensable in detecting latent mastitis and organizing its treatment. Therefore, constant monitoring of the registration and detection of somatic cells is the guarantee of getting high quality milk.

\section{References}

1. Araksyants, A.E. (2016). The Guarantee of Getting "Healthy" Milk-Agro-Culture, - V.5, - pp. 36-38 (in Armenian).

2. CU TC 021/2011, Technical Regulation on Food Safety.

3. CU TC 033/2013 Technical Regulation on the Safety of Milk and Dairy Products.

4. http://milkfacts.info/Milk\%20Microbiology/Mastitis $\% 20$ and\%20SCC.htm (accessed on 13.03.2021).

5. https://ahdb.org.uk/somatic-cell-count-milk-qualityindicator (accessed on 22.02.2021).

6. https://corporate.delaval.com/2015/03/long-live-thehealthy-cow/(accessed on 22.02.2021).

7. https://ec.europa.eu/jrc/en/science-update/referencematerial-somatic-cell-counting (accessed on 16.03.2021).

8. https://fsvps.gov.ru/fsvps/news/ld/151894.html (accessed on 26.02.2021).

9. https://www.delaval.com/globalassets/inriver-resources/ document/brochure/au-dcc-cell-counter-brochure-2018oceania.pdf (accessed on 22.02.2021).

10. https://www.journalofdairyscience.org/ article/S0022-0302(20)31066-3/fulltext (accessed on 22.02.2021).

11.https://www.ncbi.nlm.nih.gov/pmc/articles/ PMC5993762/ (accessed on 27.02.2021). 